\title{
Peningkatan Hasil Belajar Meringkas Teks Eksplanasi menggunakan Modle Mind Mapping dengan Penguatan Karakter Tanggung Jawab pada Siswa Kelas V SDN Sumber 02 Kabupaten Blitar
}

\author{
Ike Rahmawati*, Sutansi, Ferril Irham Muzaki \\ Universitas Negeri Malang, Jl. Semarang No. 5 Malang, Jawa Timur, Indonesia \\ *Penulis korespondensi, Surel: ikerahma27@gmail.com
}

Paper received: 2-2-2021; revised: 20-2-2021; accepted: 27-2-2021

\begin{abstract}
This study aims to describe application and improvement learning result of summarizing explanatory text use mind mapping by strengthening the character of responsibility. Type of research is classroom action research. By means 4 stages, they are, plan, implementation, observation, and reflection. The result showed an increase in the percentage of teacher activity from cycle I to cycle II which is 84 percent to 100 percent. Student activity also increased from 80 percent to 88 percent. Student learning result of knowledge aspect had increased from cycle I to cycle II with classical learning completeness from 78 percent to 88 percent. Student learning result of skill aspect had increased in cycle I to cycle II with classical learning completeness from 65 percent to 88 percent.
\end{abstract}

Keywords: improvement of learning outcomes; summarizing explanatory text; Mind Mapping model

\begin{abstract}
Abstrak
Penelitian ini bertujuan untuk mendeskripsikan penerapan dan peningkatan hasil belajar meringkas teks eksplanasi menggunakan model Mind Mapping dengan penguatan karakter tanggung jawab. Jenis penelitian yang digunakan adalah penelitian tindakan kelas. Melalui 4 tahap yaitu perencanaan, pelaksanaan, pengamatan dan refleksi. Hasil penelitian menunjukkan adanya peningkatan presentase aktivitas guru dari siklus I ke siklus II yaitu 84 persen menjadi 100 persen. Aktivitas siswa juga mengalami peningkatan dari 80 persen menjadi 88 persen. Hasil belajar siswa aspek pengetahuan mengalami peningkatan dari siklus I ke siklus II dengan ketuntasan belajar klasikal dari 78 persen meningkat menjadi 88 persen. Hasil belajar siswa aspek keterampilan mengalami peningkatan pada siklus I ke siklus II dengan ketuntasa belajar klasikal dari 65 persen meningkat menjadi 88 persen.
\end{abstract}

Kata kunci: peningkatan hasil belajar; meringkas teks eksplanasi; model Mind Mapping

\section{Pendahuluan}

Pembelajaran bahasa Indonesia merupakan pembelajaran wajib yang dilaksanakn pada setiap jenjang sekolah dasar, menengah hingga perguruan tinggi. Kurikulum 2013 menempatkan bahasa Indonesia sebagai penghela mata pelajaran lain dan karenanya harus berada didepan semua mata pelajaran lain. Mata pelajaran bahasa indonesesia memiliki empat aspek keterampilan yng diajarkan siswa yaitu berbicara, menyimak, mebaca dan menulis. Menurut Magdalena (2017) keterampilan menulis merupakan salah satu keterampilan yang harus diajarkan kepada siswa. Dengan menulis siswa berlatih untuk berfikir kritis dan logis. Dalam pembelajaran tidak terlepas dari kurikulum. Kurikulum yang diajarkan sekarang adalah kurikulum 2013 dengan model pembelajaran tematik terpadu. Model pembelajaran merupakan pola yang direncanakan untuk membantu pembelajaran. Hal tersebut berdasarkan pendapat Joyce \& Weil (dalam Prayoga, 2018) yang menyatakan model pembelajaran adalah 
suatu rencana atau pola yang dapat digunakan untuk membentu kurikulum (rencana pembelajaran jangka panjang), merancang bahan pembelajaran dan membimbing pembelajaran di kelas atau yang lain.

Berdasarkan hasil observasi yang dilakukan peneliti dalam pembelajaran meringkas teks yang dilakukan di SDN Sumber 02 Kabupaten Blitar, ditemukan permasalahan pada siswa yaitu siswa kurang cermat dalam membaca, siswa kurang paham tentang isi bacaan, siswa belum mendapatkan secara rinci menentukan informasi bacaan dan menyusun inti informasi yang didapatkan menjadi sebuah ringkasan, bahkan masih ada siswa yang menulis ulang teks bacaan, penggunaan tanda bacaa dan ejaan juga masih kurang tepat. Sehingga ringkasan yang dibuat siswa kurang maksimal. Rendahnya kemampuan siswa dalam meringkas teks disebabkan oleh beberapa faktor diantaranya guru memberikan penjelasan materi dengan menggunakan metode ceramah dan penugasan, guru tidak menjelaskan secara rinci menetukan informasi bacaan dan menyusun inti informasi menjadi sebuah ringkasan, banyak siswa yang ramai sendiri, tidak mendengarkan guru saat pembelajaran, siswa lamban dalam menerima informasi.

Dari hasil wawancara dengan guru kelas V di SDN sumber 02 Kabupaten Blitar, siswa kelas V berjumlah 20 siswa terdari dari 11 siswa laki-laki dan 9 siswa perempuan. Dari 20 siswa terdapat 8 siswa atau 40\% yang mencapai nilai 70 kriteria ketuntasan minimal (KKM) dan sebanyak 12 siswa atau 60\% lainnya masih mendapat nilai dibawah KKM. Gambaran kegiatan meringkas teks yang disampaikan pleh guru diatas kurang sesuai dengan pendapat Mulyati. Adapun prosedur membuat ringkasan menurut Mulyati (2009) antara lain, (1) membaca teks asli dengan seksama; (2) menyeleksi ide pokok dan ide penjelas yang benar-benar menyokong ide pokok untuk dijadikan dasar menyusun ringkasan; (3) menulis ringkasan dalam bentuk lebih singkat, utuh dan padu berdasarkan ide pokok yang telah ditemukan dengan bimbingan guru; (4) mengkoreksi ringkasan serta membandingkan isi ringkasan dengan teks asli.

Permasalahan pembelajaran meringkas teks di SDN Sumber 02 Kabupaten Blitar untuk siswa kelas V dapat diatasi salah satunya dengan model Mind Mapping. Menurut Silberman "Mind Mapping atau pemetaan pikiran merupakan cara kreatif bagi setiap pembelajar untuk menghasilkan gagasan, mencatat apa yang dipelajari, atau merencanakan tugas baru". Model Mind Mapping akan membantu siswa mengatasi kesulitan-kesulitan dalam menulis (Shohimin, 2016:105). Dalam model Mind Mapping siswa dilatih untuk mengembangkan imajinasi dan menggali ide-ide kreativitasnya dalam bentuk peta pikiran, gambar, ataupun simbol-simbol. Berpedoman pada Mind Mapping yang telah dibuat siswa, siswa dapat dengan mudah merangkai dan mengembangkan gagasan utama menjadi rangkaian teks bacaan. Adapun kelebihan dari model Mind Mapping adalah membantu siswa mengembangkan ide-ide yang muncul dalam pemikiran sehingga siswa berpikir secara kreatif, membantu siswa memahami dan mengingat materi lebih mendalam, menyenangkan bagi siswa karena penggunaan komponen warna, gambar, simbol, dan garis lengkung. Sehingga menimbulkan suasana yang positif dalam pembelajaran dikelas.

Dalam pembelajaran penanaman karakter juga diperlukan oleh guru. Pendidikan karakter secara sadar mengarahkan siswa untuk berperilaku baik, luhur sehingga siswa dapat mematuhi aturan yang berlaku dan dapat berkerjasama baik dilingkungan sekolah maupun masyarakat. (Ali \& Aisyah, 2018). Tujuan dari pendidikan karakter adalah mengkoreksi perilaku yang bertentangan dengan aturan di sekolah. Dari pendidikan karakter, 
mengharapkan siswa dapat berberilaku madiri, pengetahuannya dapat meningkat, dan dapat mengamalkan karakter yang bernilai positif dalam kehidupan sehari-hari.

Sehingga penelitian ini, menggunakan nilai karakter yang dipakai menyesuaikan dengan model pembelajaran yang digunakan yaitu model pembelajaran mind mapping cocok diterapkan dengan nilai karakter bertanggung jawab. Tanggung jawab merupakan suatu karakter yang dapat dibentuk dalam pembelajaran. Aqib \& Sujak, (2011) berpendapat bahwa karakter tanggung jawab dibentuk atas dasar perilaku yang bertujuan untuk melaksanakan tugas dan kewajibannya terhadap diri sendiri, sikap dan perilaku seseorang dalam menjalankan tugas dan kewajibannya terhadap diri sendiri, lingkungan dinamakan dengan karakter tanggung. Karena dalam membuat ringkasan teks eksplanasi, siswa mencari informasi menetukan ide pokok bacaan dengan membuat mind mapping sesuai dengan kreatifitasnya. Pembutan mind mapping dilakukan secara berkelompok. Sehingga tanggung jawab dapat dilihat dari pembagian tugasnya.

Keberhasilan penggunaan model Mind Mapping dapat meningkatkan kemampuan siswa dalam menulis ringkasan dikuatkan oleh penelitian Purwatiningsih (2019) menunjukkan peningkatan hasil belajar siswa menggunakan model Mind Mapping siklus I sebesar 75,22\% dan mengalami peningkatan pada siklus II sebesar 87,9\%. Begitu pula dengan hasil penelitian yang dilaksanakan Santoso (2017) menunjukkan peningkatan karakter tanggung jawabsiklus I sebesar 76,35\% dan meningkat pada siklus II sebesar 83,92\%. Sehingga dapat disimpulkan dari kedua penelitian bahwa penerapan model Mind Mapping dengan karakter tanggung jawab dalam pembelajaran mampu meningkatkan ativitas dan hasil belajar siswa.

Berdasarkan uraian diatas, aritekel ini akan membahas mengenai penerapan model Mind Mapping materi meirngkas teks eksplanasi dengan penguatan karakter tanggung jawab dan peningkatan hasil belajar meringkas teks eksplanasi menggunakan model Mind Mapping dengan penguatan karakter tanggung jawab pada siswa kelas V SDN Sumber 02 Kabupaten Blitar.

\section{Metode}

Pendekatan penelitian yang dilakukan dalam penelitian ini adalah pendekatan penelitian kualitatif dengan jenis penelitian tindakan kelas (PTK). Penelitian tindakan kelas merupakan jenis penelitian tindakan yang dilakukan guru kelas terhadap siswa yang bertujuan untuk memperbaiki atau meningkatakan mutu pemeblajaran (Arikunto dkk,2016). Rancangan yang digunakan dalam penelitian ini mengacu model yang dikemukakan oleh Kemis dan M.C Taggart (dalam Arikunto,2013) dengan empat tahap yaitu perencanaan (plan), tindakan (act), pengamatan (observe), dan refleksi (reflect).

Subjek penelitian adalah guru dan siswa kelas V SDN Sumber 02 kabupaten Blitar tahun ajaran 2019/2020 yang berjumlah 20 siswa, terdiri dari 11 siswa laki-laki dan 9 siswa perempuan. Data dala penelitian ini meliputi data penerapan model Mind Mapping dan data hasil belajar siswa. Data penerapan model Mind Mapping dipeorleh melalui hasil pengamatan aktivitas guru dan siswa selama proses pembelajaran menggunkan mosel Mind Mapping. Data yang digunakan untuk mengetahui hasil belajar siswa berupa data penilaian pengetahuan dan keterampilan. Teknik pengumpulan data dalam penelitian ini meliputi obesrvasi, wawancara, tes, dokumentasi, dan catatan lapangan. 
Langkah yang digunakan dalam analisis data penelitian yang dikemukakan Miles \& Hurman (dalam Sugiono, 2013) meliputi reduksi data, penyajian data, dan penarikan kesimpulan. Data yang digukan untuk menjawab rumusan masalah tentang penerapan model Mind Mapping untuk meringkas teks eksplansi dengan penguatan karakter tanggung jawab siswa kelas V SDN Sumber 02 Kabupaten Blitar berasal dari aktivitas guru dalam menerapkan model pembelajaran Mind Mapping dan aktivitas siswa dalam mengikuti pelaksanaan pembelajaran menggunakan Model Mind Mapping. Sedangkan data yang digunakan untuk menjawab rumusan masalah tentang peningkatan hasil belajar siswa meringkas teks eksplanasi menggunakan Model Mind Mapping dengan pengutan karakter tanggung jawab siswa kelas V SDN Sumber 02 Kabupaten Blitar bersal dari hasil belajar siswa aspek pengetahuan dan aspek keterampilan meringkas siswa.

\section{Hasil dan Pembahasan}

\subsection{Hasil}

Berdasarkan kegiatan pembelajaran pada tahap pratindakan, peneliti memperoleh data hasil belajar siswa materi meringkas teks yang dilakukan oleh guru kelas $\mathrm{V}$ belum tuntas. Hal itu diketahui masih banyak siswa yang mendapatkan nilai dibawah KKM yang ditentukan yaitu 70. Dari 20 siswa, terdapat 8 siswa yang dinyatakan tuntas dan 12 siswa lainnya belum tuntas. Apabila dihitung dengan presentase, ketuntasan belajar siswa mencapai $40 \%$, sedangkan siswa yang belum tuntas mencapai $60 \%$. Refleksi pada tahap pratindakan dapat diketahui informais sebagai berikut (1) guru hendaknya menyampaikan apersepsi dan tujuan pembelajaran; (2) metode yang digunakan oleh guru antara lain ceramah dan pemberian tugas saja sehingga kurang mengembangkan kereativitas siswa; (3) penyampaian materi meringkas kurang terperinci; (4) guru hendaknya mengajak siswa melakukan kegiatan tanya jawab mengenai materi yang belum dipahami, sehingga suasana kelas terkesan pasif; (5) guru hendaknya memberikan bimbingan kepada siswa pada setiap tahap meringkas; (6) guru hendaknya mengajak siswa mengoreksi hasil ringkasan yang telah dibuat; (7) guru hendaknya meminta siswa mempresntasikan hasil ringkasan didepan kelas; (8) pada akhir kegiatan guru hendaknya mengajak siswa membuat kesimpulan dan refleksi mengenai materi membuat ringkasan; (9) hasil belajar siswa dari pelaksanaan pratindakan masih rendah terbukti dengan presentase ketuntasan belajar klasikal yang diperoleh sebesar $60 \%$ dengan kriteria perlu bimbingan.

Pelaksanaan pembelajaran dengan menggunakan model Mind Mapping dapat dilihat dari aktivitas guru dan aktivitas siswa. Penilaian aktivitas guru dilihat dari muncul tidaknya tahapantahapan model Mind Mapping. Keterlaksanaan penerapan model Mind Mapping dapat dilihat pada aktivitas guru dan aktivitas siswa yang mengalami peningkatan dapat dilihat pada Tabel 1. 
Jurnal Pembelajaran, Bimbingan, dan Pengelolaan Pendidikan, 1(2), 2021, 120-129

Tabel 1. Rekapitulasi Aktivitas Guru dan Siswa pada Penerapan Model Mind Mapping Siklus I dan II

\begin{tabular}{llllll}
\hline & & Siklus I & & Siklus II & \\
\cline { 3 - 6 } No & Aktivitas & Pertemuan 1 & Pertemuan 2 & Pertemuan 1 & Pertemuan 2 \\
\hline 1 & Guru & $81 \%$ & $86 \%$ & $100 \%$ & $100 \%$ \\
& Kriteria & Baik & Baik & Sangat baik & Sangat baik \\
& Rata-rata & $84 \%$ & & $100 \%$ & \\
& kriteria & Baik & & Sangat baik & \\
2 & Siswa & $78 \%$ & $81 \%$ & $84 \%$ & $91 \%$ \\
& Kriteria & cukup & Baik & Baik & Sangat baik \\
& Rata-rata & $80 \%$ & & $88 \%$ & \\
& kriteria & baik & & Baik & \\
\hline
\end{tabular}

Berdasarkan Tabel 1 dapat diketahui bahwa aktivitas guru dalam melaksanakan pembelajaran dan aktivitas siswa dalam mengikuti pembelajaram menggunakan model Mind Mapping mengalami peningkatan dari siklus I ke siklus II. Pada siklus I rata-rata presentase guru mencapai 84\% dengan kriteria keberhasilan baik. Ketercapaian 84\% terjadi karena dalam pelaksanaan pembelajaran masih terdapat langkah-langkah model Mind Mapping yang terlewatkan oleh guru, kegiatan tersebut meliputi: guru belum melakukan kegiatan apersepsi, guru belum membimbing siswa untuk menambahkan cabang-cabang setiap poin pada ide pokok dalam membuat Mind Mapping, guru belum meminta siswa memberikan tanggapan atau masukan kepada kelompok yang melakukan presentasi sehingga kegiatan diskusi terkesan pasif, guru hendaknya memberikan motivasikepada siswa agara siswa percaya diri dalam menyampaikan hasil diskusinya di depan kelas, guru hendaknya meningkatkan pengelolaan kelas. Pada siklus II, aktivitas guru sudah berjalan dengan baik sesuai dengan langkah-langkah model Mind Mapping. Guru sudah melakukan pembenahan di siklus II, sehingga pada siklus II rata-rata aktivitas guru mencapai 100\% dengan kriteria keberhasilan sangat baik.

Presentase rata-rata aktivivtas siswa pada siklus I sebesar $80 \%$ dengan kriteria keberhasilan baik, kekurangan siswa pada siklus I meliputi: antusias siswa dalam emmbaca teks bacaan dan menuliskan ide pokok dengan simbol masih kurang, masih ada siswa yang tidak memperhatikan penjelasan guru, siswa tidak memberikan tanggapan kepada kelompok yang presentasi, sehingga diskusi terkesan pasif, siswa kurang percaya diri dalam menyampaikan hasil diskusi di depan kelas, siswa membutuh waktu tambahan dalam menyelesaikan tugas. Presentase rata-rata aktivitas siswa pada siklus II meningkat sebesar 88\% dengan kriteria keberhasilan baik, karena siswa telah mengikuti langkah-langkah pembelajaran dengan baik sehingga hasilnya meningkat. Peningkatan aktivitas siswa pada siklus I ke siklus II dengan kriteria keberhasilan baik.

Berdasarkan paparan temuan penelitian menunjukkan bahwa penerapan model Mind Mapping pada pembelajaran meringkas teks eksplanasi di kelas V SDN Sumber 02 Kabupaten Blitar dapat dilaksanakan guru sangat baik dan siswa juga dapat mengikuti pembelajaran sangat baik.

Pelaksanaan pembelajaran meringkas teks eksplanasi melalui model Mind Mapping sudah berjalan dengan baik. Dari pelaksanaan proses pemeblajaran diperoleh hasil belajar siswa melalui aspek pengetahuan dan aspek keterampilan siswa. Hasil belajar siswa aspek 
pengetahuan diambil dari rata-rata LKK dan evaluasi siwa, aspek keterampilan diambil dari hasil ringkasan siswa. Hasil belajar siswa aspek pengetahuan dapat dilihat pada Tabel 2.

Tabel 2. Rekapitulasi Hasil Belajar siswa Aspek Pengetahuan Siklus I dan II

\begin{tabular}{lllll}
\hline & Siklus I & \multicolumn{3}{c}{ Siklus II } \\
\cline { 2 - 5 } & P 1 & P 2 & P 1 & P 2 \\
\hline Jumlah & 1536 & 1589 & 1632 & 1703 \\
Rata-rata & 77 & 79 & 82 & 85 \\
Presentase ketuntasan klasikal & $70 \%$ & $80 \%$ & $85 \%$ & $90 \%$ \\
Kriteria keberhasilan & Cukup & Baik & Baik & Sangat baik \\
\hline
\end{tabular}

Berdasarkan Tabel 2 dapat diketahui bahwa hasil belajar siswa aspek pengetahuan mengalami peningkatan dari siklus I ke siklsu II. Hal itu dapat dilihat dari nilai rata-rata kelas disetiap pertemuan. Pada siklus I pertemuan 1 nilai rata-rata mencapai 77, dimana presentase ketuntasan belajar klasikal 70\% dengan kriteria keberhasilan cukup. Siklus I peretmauan 2 nilai rata-rata mencapai 79 , dimana presentase ketuntasan belajar klasikal $80 \%$ dengan kriteria keberhasilan baik. Pada siklus II pertemuan 1 nilai rata-rata mencapai 82, dimana prresentase ketuntasan belajar klasikal 85\% dengan kriteria keberhasilan baik. Siklus II pertemuan 2 nilai rata-rata mencapai 85, dimana ketuntasan belajar klasikal 90\% dengan kriteria keberhasilan sangat baik. Sehingga dapat diketahui bahwa peningkatan hasil eblajar siswa aspek ketuntasan dari siklus I ke siklus II mencapai 13\%. Selain itu, hasil belajar siswa spek keterampilan dapat dilihat pada Tabel 3.

Tabel 3. Rekapitulasi Hasil Belajar Siswa Aspek Keterampilan Siklus I dan II

\begin{tabular}{|c|c|c|c|c|c|}
\hline \multirow{2}{*}{ Aspek Penilaian } & \multicolumn{2}{|c|}{ Siklus I } & \multicolumn{2}{|c|}{ Siklus II } & \multirow{2}{*}{$\begin{array}{l}\text { Peningkatan dari } \\
\text { siklus I ke siklus I }\end{array}$} \\
\hline & P 1 & P 2 & P 1 & P 2 & \\
\hline Jumlah siswa tuntas & 12 & 14 & 17 & 18 & \\
\hline Presentase ketuntasan & & & & & \\
\hline klasikal & $60 \%$ & $70 \%$ & $85 \%$ & $90 \%$ & \\
\hline Rata-rata & \multicolumn{2}{|c|}{$65 \%$} & \multicolumn{2}{|c|}{$88 \%$} & \\
\hline Kriteria Keberhasilan & \multicolumn{2}{|c|}{ Kurang } & \multicolumn{2}{|c|}{ Baik } & $23 \%$ \\
\hline
\end{tabular}

Berdasarkan Tabel 3 dapat diketahui hasil belajar siswa aspek keterampilan juga mengalami peningkatan dari siklus I ke siklus II. Hal ini dapat dilihat rat-rat ketuntasan belajar aspek keterampilan pada siklus I sebesar 65\% dengan kriteria keberhasilan kurang. Hasil eblajar siswa aspek keterampilan pada siklus II sebesar 88\% dengan kriteria keberhasilan baik. Sehingga hasil belajar siswa aspek keterampilan siklus I ke siklus II mengalami peningkatan sebesar $23 \%$.

Berdasarkan paparan temuan penelitian di atas menunjukkan terjadinya peningkatan hasil belajar siswa melalui model Mind Mapping dengan penguatan karakter tanggung jawab pada materi meringkas teks eksplanasi pada siswa kelas V SDN Sumber 02 Kabupaten Blitar. Peningkatan hasil belajar siswa dapat dilihat dari aspek pengetahuan dan aspek keterampilan membuat ringkasan. 


\subsection{Pembahasan}

Penerapan model Mind Mapping materi meringkas teks eksplanasi dilaksanakan sebanyak 2 siklus, yaitu siklus I dan siklus II. Pada pelaksanaan siklus I dan siklus II guru sudah melaksankan pembelajaran sesuai dengan langkah-langkah RPP. Langkah-langkah pemeblajaran RPP sudah disesuaikan dengan langkah pembelajaran model Mind Mapping, Tetapi pada siklus I belum terlaksana dengan maksimal, sehingga masih terdapat langkahlangkah yang terlewatkan.

Pada siklus I dapat diperoleh hasil pengamatan melalui aktivitas guru, bahwa guru belum melakukan kegitan apersepsi, pada tahap tersebut guru belum membimbing siswa untuk menambahkan cabang-cabang setiap poin pada ide pokok yang didapatkan, sehingga siswa merasa kesulitan dalam menentukan ide pokok dalam membuat Mind Mapping. Hal ini belum sesuai dengan pendapat Mulyati (2009:1.7) bahwa siswa harus memahami isi bacaan, sehingga siswa tidak merasa kesulitan dalam menentukan ide pokok dan ide penjelas untuk menyusun ringkasan. Guru belum meminta siswa memberikan tanggapan kepada kelompok yang melakukan presentasi, sehingga kegiatan diskusi terkesan pasif. Guru perlu menjelaskan materi secara terperinci kepada siswa tentang kegiatan pemeblajaran yang akan dilakukan, karena siswa belum terbiasa dengan pembelajaran menggunakan model Mind Mapping. Antusias siswa dalam membaca teks bacaan dan menuiskan ide pokok dangan simbol masih kurang. Siswa juga masih kurang percaya diri dalam menyampikan hasil diskusinya di depan kelas, sehingga perlu ditunjuk oleh guru. Diskusi terkesna pasif, karena siswa tidak memberikan tanggapan kepada kelompok yang presentasi. Waktu yang digunakan dalam mengerjakan evaluasi memerlukan waktu tambahan. Dalam pembelajaran, guur sudah melakukan kegiatan monitoring atau pengawasan kepada setiap kelompok, sehingga siswa yang merasa kesulitan bisa berperan aktif dalam diskusi kelompok. Ketika guru menyampikan materi masih ada siswa yang tidak memperhatikan. Sehingga guru memerlukan pengelolaan kelas yang baik dan bisa membangkitkan semangat siswa.

Pada kegiatan pemeblajaran materi meringkas teks eksplanasi menggunakan model Mind Mapping di siklus II, guru telah memperbaiki permasalahn yang terjadi di siklus I. guru sudah melakukan langkah-langkah kegiatan menggunakan model Mind Mapping dengan baik dan tidak ada yang terlewatkan. Sehingga proses pembelajaran di siklus II lebih baik dari siklus i. pada pembelajaran di siklus II sebagian besar siswa mulai aktif mengikuti proses pembelajaran, siswa sudah memberikan tanggapan kepada kelompok yang menyampikan haisl diskusinya, siswa mampu bekerjasama dengan kelompoknya, siswa mulai paham cara menentukan ide pokok denganmenggunkan model Mind Mapping sehingga dapat membuat sebuah ringkasan. Tetapi dalam mengerjakan evaluasi masih memerlukan waktu tambahan, karena ada siswa yang ramai dan mengganggu teman yang lain, sehingga tidak bisa konsentrasi. Siswa juga sudah percaya diri dalam menyampikan hasil diskusinya di depan kelas, tetapi masih ada beberapa siswa yang malu dan memerlukan motivasi guru.

Kegiatan pembelajaran meringkas teks eksplanasi yang dilakukan oleh guru sudah berjalan lancara sesuai dengan langkah-langkah pembelajaran menggunakan model Mind Mapping. Adapaun langkah-langkah model Mind Mapping menurut Shohimin (2016:106) adalah (1) guru menyamikan tujuan pembelajaran yang ingin dicapai; (2) guru menyajikan materi pembelajaran sebagaimana biasa; (3) untuk mengetahui daya serap siswa, bentuklah kelompok berpasangan dua orang; (4) suruhlah seseorang dari pasangan itu menceritakan 
materi baru yang diterima guru dan pasangannya mendengar sambil membuat catatan-catatan kecil, kemudian berganti peran. Begitu juga kelompok lainnya; (5) seluurh siswa secra bergiliran atau acak menyampaikan hasil wawancaranya dengan teman pasangannya, sampai sebagian siswa sudah menyampaikan hasil wawancaranya; (6) guru mengulangi tau menjelaskan kembali materi yang sekiranya belum dipahami siswa; (7) kesimpulan atau penutup. Sedangkan Deporter (dalam Shohimin, 2016:106) menyatakan bahwa dalam membuat Mind Mapping ada empat yaitu: (1) tulis gaggasan utama di tengah-tengah kertas dan lingkupilah dengan lingkaran, persegi, atau bentuk lain; (2) tambahkan sebuah cabang yang keluar dari pusatnya untuk setiap poin atau gagasan utama. Jumlah cabang akan bervariasi, tergantung dari jumlah gagasan atau segmen. Gunakan warna yang berbeda setiap cabang; (3) tiliskan kata kunci atau frasa pada tiap-tiap cabang yang dikembangkan untuk detail. Kata-kata kunci adalah kata-kata yang menyampaikan inti sebuah gagasan dan memicu ingatan siswa; (4) tambahkan simbol atau ilustrasi untuk mendapatkan ingatan yang lebih baik.

Berdasakan hasil penelitian, pada aktivitas siswa siklus I terdapat beberapa hambatan antara lain siswa belum paham cara membuata Mind Mapping atau peta pikiran, sehingga siswa kesulitan menentukan ide pokok. Sebagian besar siswa kurang percaya diri dalam menyampikan hasil diskusi di depan kelas, siswa juga kurang aktif memberikan tanggapan ketika ada kelompok yang menyampaikan hasil diskusinya, masih banyak siswa ramai, belum terbiasa bekerja kelompok dan tidak memperhatikan materi yang disampikan oleh guru, yang mengakibatkan dalam kegiatan evaluasi membutuhkan waktu tambahan dalam mengerjakan. Permasalahan ini terjadi karena siswa belum terbiasa menggunkan model Mind Mapping.

Aktivitas siswa pada siklus II sudah mengalami peningkatan dibandngkan pada siklus I. Pada siklus II siswa aktif dan terbiasa bekerjasama dengan kelmpoknya, siswa sudah memahami cara menentukan ide pokok dan membuat Mind Mapping sehingga dapat menulis ringkasan tanpa sering bertanya kepada guru. Siswa juga aktif mengikuti pembelajaran, percaya diri dalam menyampaikan hasil diskusi dan memberikan tanggapan di depan kelas, kegiatan evaluasi membutuhkan waktu tambahan. Peningkatan aktivitas ini disebabkan karena siswa sudah mulai paham dan terbiasa menggunkan model Mind Mapping dalam pembelajaran.

Aktivitas guru dan aktivtas siswa pada siklus I ke siklus II mengalami peningkatan. Hal itu dapat dilihat dari presentase aktivitas gur pada siklus I sebesar $84 \%$ dengan kriteria keberhasilan baik mengalami peningkatan pada siklus II menjadi 100\% dengan kriteria keberhasilan sangat baik. Sedangkan presentase aktivita siswa pada siklus I sebesar $80 \%$ dengan kriteria keberhasilan baik mengalami peningkatan pada siklus II sebesar 88\% dengan kriteria keberhasilan baik. Selaint itu, ketuntasan belajar klasikal aspek keterampilan menulis ringkasan juga mengalami peningkatan pada siklus II. Pada siklus I ketuntasan belajar klasikal aspek ketermapilan menulis ringkasan diperoleh presentase sebesar $65 \%$ dengan kriteria keberhasilan kurang mengalami peningkatan pada siklus II sebesar 88\% dengan kriteria keberhasilan baik. Adanya peningkatan pada aktivitas sesuai dengan pendapat Shohimin (2016:106) bahwa penerapan model Mind Mapping dapat meningkatakan keaktifan siswa, kepercayaan diri siswa, mengasah kreativitas siswa, dan membantu memudahkan siswa dalam mengingat materi. 
Hal ini dapat disimpulkan berdasarkan uraian diatas, bahwa materi meringkas teks eksplanasi menggunkan model Mind Mapping yang dilaksanakan pada siklus I dan siklus II mengalami peningkatan aktivitas guru, aktivitas siswa, dan ketuntasan belajara klasikal aspek keterampilan menulis ringkasan. Hal ini sesuai dengan penelitian Santoso (2017) dan Purwantiningsih (2019) dimana terjadi peningkatan pada aktivitas dan keterampilan dalam menerapkan pembelajaran menggunakan Mind Mapping.

Selain itu, model Mind Mapping yang diterapkan dalam pembelajaran meringkas teks eksplanasi pada siswa kelas V SDN Sumber 02 Kabupaten Blitar bertujuan untuk meningkatakan kemampuan siswa dalam meringkas teks eksplanasi. Sesuai dengan pendapat Sudjana (2010:3) menyatakan bahwa hasil belajar merupakan perubahan tingkah laku yang mencakup aspek dibidang kognitif, aspek afektif, dan aspek psikomotor. Hal ini dibuktikan dari hasil belajar siswa mengalami peningkatan pada siklus I ke siklus II.

Hasil belajar materi meringkas teks pada tahap pratindakan yang diperoleh siswa, masih banyak yang mendapatkan nilai dibawah KK yang ditentukan. Dari 20 siswa, terdapat 8 siswa mencapai nilai KKM dan 12 siswa lainnya masih mendapat nilai dibawah KKM. Apabila dihitung dengan presentase ketuntasan belajar klasikal siswa mencapai 40\% dengan kriteria ketuntasan perlu bimbingan. Sedangkan siswa yang belum tuntas mencapai $60 \%$ dan rata-rata sebesar 67. Presentase tersebut masih jauh dari presentase yang ditentukan yaitu $80 \%$. Sehingga dilakukan perbaikan pelaksanaan pembelajaran maetri meringkas teks eksplanasi menggunakan model Mind Mapping pada siklus I dan siklus II.

Pada siklus I diperoleh data ketuntasan belajar klasikal aspek pengetahuan dengan ratarat $75 \%$ dengan kriteria keberhasilan cukup. Hal ini dikarenakan siswa belum mampu membuat ringkasan dengan benar dan masih kesulitan dalam menentukan inti bacaan dari kegiatan menentukan ide pokok dan ide penjelas. Pada pertemuan 1, dari 20 siswa sebanyak 14 siswa telah mencapai kriteria ketuntasan minimal, sedangkan 6 siswa lainnya belum mencapai kriteria ketuntasan minimal. Pada pertemuan 2, dari 20 siswa sebanyak 16 siswa telah mencapai kriteria ketuntasan minimal, sedangkan 4 siswa lainnya belum mencapai kriteria ketuntasan minimal. Sedangkan ketuntasan belajar siswa aspek keterampilan diperoleh dengan rata-rata 65\% dengan kriteria keberhasilan kurang. Hal ini dikarenakan siswa masih kesulitan dalam menyusun ringkasan sesuai ejaan bahasa Indonesia yang baik dan benar. Pada pertemuan 1, dari 20 siswa sebanyak 12 siswa mancapai kriteria ketuntasan minimal, kemudian pada pertemuan 2 mengalami peningkatan menjadi 14 siswa yang mencapai ketuntasan maksimal. Berdasarkan data siswa yang diperoleh, siswa belum mencapai ketuntasan belajar klasikal yaitu $80 \%$. Sehingga perlu adanya perbaikan pada siklus II.

Pada siklus II pembelajaran yang dilakukan guru menggunakan model Mind Mapping sudah berhasil dan mengalami peningkatan. Siswa sudah mampu membuat ringkasan dengan benar dapat menentukan ide pokok dan penjelas sesuai dengan langkah-langkah. Hal ini dibuktikan dengan hasil belajar siswa aspek pengetahuan diperoleh rata-rata sebesar $80 \%$ dengan kriteria keberhasilan baik. Pada pertemuan 1, dari 20 siswa sebanyak 17 siswa telah mencapai kriteria kentuntasan minimal, sedangkan 3 siswa lainnya belum mencapai kriteria ketuntasan minimal. Pada pertemuan 2, dari 20 siswa sebanyak 18 siswa telah mencapai kriteria ketuntasan minimal. Sedangkan ketuntasan belajar aspek keterampilan diperoleh dengan rata-rata 88\% dengan kriteria keberhasilan baik. Pada pertemuan 1, dari 20 siswa 
sebanyak 17 siswa mencapai kriteria ketuntasan minimal, kemudian pada pertemuan 2 mengalami peningkatanmenjdai 18 siswa yang mencapai kriteria ketuntasan minimal. Sehingga berdsasarka data yang diperoleh hasil belajar siswa menulis ringkasan mencapai kriteria ketuntasan belajar klasikal yaitu $88 \%$.

Berdasarkan uraian diatas, dapat disimpulkan bahwa penerapan model Mind Mapping dengan penguatan karakter tanggung jawab pada pembelajaran meringkas teks eksplanasi dapat meningkatakan hasil belajar siswa kelas V SDN Sumber 02 Kabupaten Blitar. Peningkatan belajar ini sesuai dengan penelitian terdahulu yang dilakukan oleh Santoso (2017) menunjukkan adanya peningkatan hasil belajar melalui model Mind Mapping berabasis karaker tanggung jawab pada siswa kelas V SDN Jepang Pakis Kudus. Selain Santoso, penelitian yang dilakukan Purwantiningsih (2019) dengan penerapan model Mind Mapping dapat meningkatakan hasil belajar meringkas cerita menggunakan model Mind Mapping pada siswa kelas III SDN Jantiganggong Kabupaten Jombang.

\section{Simpulan}

Berdasarkan hasil penelitian yang dilakukan di SDN Sumber 02 Kabupaten Blitar, dapat disimpulkan bahwa penerapan model Mind Mapping pada materi meringkas teks eksplanasi dengan penguatan karakter tanggung jawab pada siswa kelas V SDN Sumber 02 Kabupaten Blitar, terlaksana dengan baik sesuai dengan langkah-langkah model pembelajaran Mind Mapping. Hal ini dapat dibuktikan dengan rata-rata presentase aktivitas gur pada siklus I sebesar $84 \%$ dengan kriteria keberhasila baik dan meningkat pada siklus II dengan rata-rata presentase aktivitas guru sebesar $100 \%$ dnegan kriteria keberhasilan sangat baik. Peningkatan juga terjadi pada rata-rata presentase aktivitas siswa pada siklus I sebesar $80 \%$ dengan kriteria keberhasilan baik dan mengalami peningkatan pada siklus II sebesar $88 \%$ dengan kriteria keberhasilan baik.

Selain aktivitas guru dan aktivitas siswa, pelaksanaan pembelajaran model Mind Mapping dapat meningkatkan hasil belajar siswa dalam menentukan ide pokok dan menyusun ringkasan seuai dengan ido pokok yang telah didapatkan. Hal itu dapat dibuktikan dari hasil belajar siswa aspek pengetahuan siklus I diperoleh rata-rata sebesar 78\% dengan kriteria keberhasilan cukup. Pada siklus II hasil belajar siswa aspek pengetahuan mengalami peningkatan sebesar 88\% dengan kriteria keberhasilan baik. Hasil belajar siswa aspek keterampilan siklus I diperoleh rata-rata sebesar 65\% dengan kriteria keberhasilan kurang. Pada siklus II hasil belajar siswa aspek keterampilan juga mengalami peningkatan sebesar $88 \%$ dengan kriteria keberhasilan baik. Sehingga hasil belajar siswa aspek keterampilan dari siklus I ke siklus II mengalami peningkatan sebesar $23 \%$.

Dalam melaksanakan pembelajaran dengan menerapkan model Mind Mapping dengan materi meringkas teks eksplanasi sangat baik diterapkan di SDN Sumber 02 Kabupaten Blitar. Dalam penelitian ini hendaknya guru menguasai langkah-langkah pembelajaran menggunakan model Mind Mapping, agar pembelajaran berjalan maksimal dan tidak ada langkah-langkah yang terlewatkan. Sehingga hasil belajar siswa dapat meningkat.

\section{Daftar Rujukan}

Ali \& Aisyah. (2018). Pendidikan Karakter Konsep dan Implementasinya. Jakarta: Prenadamedia Group.

Aqib, Z. \& Sujak. (2011). Panduan dan Aplikasi Pendidikan Karakter. Bandung: Yrama Media.

Arikunto, S. (2013). Prosedur Penelitian Suatu Pendekatan Praktik. Jakarta: PT Rineka Cipta. 
Jurnal Pembelajaran, Bimbingan, dan Pengelolaan Pendidikan, 1(2), 2021, 120-129

Arikunto, S., Suhardjono, \& Supardi. (2016). Penelitian Tindakan Kelas. Jakarta: Bumi Aksara.

Magdalena, R. (2017). Peningkatan Keterampilan Menulis Ringkasan Teks Bacaan Melalui Model Pembelajaran Teknik CIRC (Cooperative Integrated Reading Composition). Deiksis, 9(2), 194-203.

Mulyati, Y. (2009). Keterampilan Berbahasa Indonesia SD. Jakarta: Universitas Terbuka.

Prayoga, E. A., Suwignyo, H., \& Mudiono, A. (2018). Peningkatan keterampilan menulis teks eksposisi melalui CIRC (cooperative integrated reading and composition) berbantuan video pada siswa SD. Jurnal Pendidikan: Teori, Penelitian, dan Pengembangan, 3(1), 115-120.

Purwantiningsih, E, B. (2019). Peningkatan hasil Belajar Meringkas Cerita diakses Menggunakan Model Mind Mapping Pada Siswa Kelas III SDN Jatiganggong Kabupaten Jombang. Skripsi tidak diterbitkan. Malang: FIP UM.

Santoso. (2017). Peningkatan Hasil Belajar PKN Melalui Model Mind Mapping Berbasis Karakter Tanggung Jawab Pada Siswa Kelas V SDN 3 Jepang Pakis Kudus. Doctoral dissertation, Universitas Muria Kudus.

Sudjana. N. (2010). Penilaian Hasil Dan Proses Belajar Mengajar. Bandung: PT Remaja Rosdakarya.

Shohimin. A. (2016). Model Pembelajaran Inovatif dalam Kurikulum 2013. Yogyakarta: Ar-Ruzz Media.

Sugiono. (2015). Metode Penelitian Pendidikan (Pendidikan Kuantitatif, Kualitatif, dan R\&D). Bandung: Alfabeta. 